\title{
Academic Self-efficacy and Academic Procrastination: Exploring the Mediating Role of Academic Motivation in Turkish University Students
}

\author{
Asude Malkoç*, Aynur Kesen Mutlu \\ Faculty of Education, Istanbul Medipol University, Turkey
}

Copyright(C2018 by authors, all rights reserved. Authors agree that this article remains permanently open access under the terms of the Creative Commons Attribution License 4.0 International License

\begin{abstract}
The aim of this study has been to investigate the relationships among academic self-efficacy, academic motivation, and academic procrastination. The study has further delved into the question of whether academic motivation mediates the relationship between self-efficacy and academic procrastination. In order to investigate such links, three hundred and nineteen university students (218 females and 101 males) enrolled in the education faculty of a private university in Istanbul, Turkey, offered data. For data collection, the Aitken Procrastination Inventory, Academic Self-Efficacy Scale, and Academic Motivation Scale have been used. The results of the study indicate that academic motivation partially mediate the relationship between academic self-efficacy and academic procrastination.
\end{abstract}

Keywords Academic Motivation, Academic Procrastination, Academic Self-efficacy

\section{Introduction}

Transition from high school to university brings with many difficulties for students University life can be stressful for a new student [1] and they have to overcome many challenges in pursuit of their educational goals. Sometimes students tend to perceive this situation as negative and turn into an adverse effect on students' motivation and performance [2-4]. Extensive research has been conducted with the aim of identifying those factors which promote academic achievement such as self-efficacy [5] and optimism [6], and those which inhibit academic achievement, such as academic procrastination.

There has been a growing interest in the concept of academic procrastination especially in academic settings. Academic procrastination is a risk factor for students' academic motivation and success. For this reason, it needs to be studied on reducing academic procrastination and increase academic self-efficacy in school settings.

\subsection{Academic Procrastination}

Academic procrastination is a form of procrastination specific to academic settings. It involves knowing that one needs to carry out an academic task or undertake an academic activity, such as writing a term paper, studying for examinations, finishing a school related project, or undertaking the weekly reading assignments, but, for one reason or another, failing to motivate oneself to do so within the expected time frame [7]. Although there is no universally accepted definition for this phenomenon, academic procrastination can be defined as the postponement of academic goals to the point where optimal performance becomes highly unlikely, resulting in a state of psychological distress [8,9].

Rothblum, Solomon and Murakami [10] define the concept according to its symptoms, such as postponing academic duties such as preparing for exams and delaying homework. On the other hand, Ferrari, Johnson and McCown [9] claim that academic procrastination is the continued avoidance of academic duties which causes students fail academically. Similarly, it can be said that academic procrastination involves postponing academic duties in a way that that is causes failure, unhappiness and stress.

Due to these significant negative aspects, researchers have studied procrastination and have proposed various cognitive, emotional, and personality variables as possible predictors. Frequently cited cognitive correlates include a tendency toward self-handicapping, low self-esteem, low academic self-efficacy, fear of failure, and distorted perceptions of available and required time to complete tasks [11-15]. With regard to emotional functioning, several studies have found that anxiety, depression, stress and worry are associated with procrastination 
$[3,9,16,17,18]$, but the empirical evidence concerning the relationship between mood and procrastination is not definitive [19]. In terms of personality features, research has consistently shown that lower conscientiousness and, to a lesser extent, higher degrees of neuroticism, can be connected to procrastination [18,20,21,22,23]. In addition, Kandemir's study [55] concluded that academic procrastination could be predicted through an analysis of academic success mean, self-regulation and life satisfaction. In a study by Klassen, Krawchuk and Sukaina [56] procrastination was also found to be related to self-regulation, academic self-efficacy, self-esteem, and self-efficacy for self-regulation.

\subsection{Academic Self-efficacy}

Self-efficacy has been defined in various ways and is described by Bandura [24] as a combination of self-confidence, self-reliance and trust in oneself. Self-efficacy does not refer to how much a person likes themselves, or how much they may enjoy the task at hand; rather, self-efficacy is concerned with how well a person believes they will be able to reach a desired outcome in a designated area [24]. In other words, self-efficacy refers to an individual's personal belief in his own efficacy capacities in order to produce a specific performance. In education, self-efficacy is a key contributing factor to learners' success, as it influences the choices learners make and the courses of action they pursue. Academic self-efficacy can be defined as the reflections of "student's personal beliefs in his own capacities to achieve educational duties at expected levels" [25]. Academic self-efficacy derived from Bandura's self-efficacy theory refers to "an individual's belief (conviction) that they can successfully achieve at designated level on an academic task or attain a specific academic goal [26-30].

Academic self-efficacy has been investigated in relation to various domains, including gender, academic motivation, and academic success. In her study, Bedel [31] looked into the relationship between academic self-efficacy, academic motivation, and attitudes towards teaching in pre-service teachers. It was concluded in the study that there was a significant relationship between academic motivation and academic self-efficacy. The findings of the study also revealed that academic self-efficacy was the predictor of academic motivation. The relationship between academic self-efficacy and motivation was also examined in the study by Husain [32]. In his study, Husain concluded that there was an association between academic self-efficacy and academic motivation of 135 undergraduate students. In another study by Ateş and Saylan [33], pre-service science teachers' academic self-efficacy and academic motivation were investigated in the Turkish context. It was concluded that there was a strong correlation between teachers' academic self-efficacy and academic motivation. In another study by Tan [58], it was found that self-efficacy for self-regulated learning was significantly and negatively related to procrastination. High self-efficacy for self-regulated learning also predicted students' expectations of doing well and low self-efficacy for self-regulated learning predicted students' expectations of not doing well academically.

\subsection{Academic Motivation}

In terms of education, motivation has a multi-dimensional structure which correlates with learning and academic motivation [Mohamadi, 2006, as cited in 34]. There are different interpretations of motivation. In the discipline of education, motivation is considered a phenomenon consisting of an individual's beliefs in their ability to carry out a specific task [35], the reasons and goals of the individual in conducting this task [36], and the emotional response concerning its being carried out [37].

Experts divide motivation into two major groups; namely, internal motivation and external motivation. While the individual influenced by the external motivation with an independent goal undertakes a specific activity, the internal motivation provides the sufficient incentive for performing the task [Mohamadi, 2006, as cited in 34]. Psychologists have noted that motivation should be taken into account in education because of its effective relationship with new learning, abilities, strategies and behaviors [38], and they have presented motivation for academic achievement as one of the preliminary constructs for defining such type of motivation [34]. Academic motivation is the driving force behind student's motivation to learn. It is the need and desire to excel in academic work [39]. It was found that there is a positive and significant relationship between achievement and academic motivation [40,41]. Köseoğlu [42] found that there is a statistically significant difference between male and female students in terms of academic motivation.

In past decades, due to the acceptance of the fact of motivation having an effect on students' academic achievement, psychologists have recognized and examined the effective factors in motivation for academic achievement. The results of this research have indicated that personality, family, university and social variables are all related to this construct [Masaali, 2007, as cited in 34]. For instance, students' self-esteem and motivation for academic achievement in particular have intrinsically affected the learning and academic achievement [43]. In addition to this, in a study by Cerino [59] motivation and intrinsic motivation showed significantly unique effects on procrastination. Others have directed their studies towards forwarding intellectual ability, learning style, personality and motivation for academic achievement as the predictors of academic achievement in higher education [44]. In one such study, focused on medical 
students, the most important motivational factor in choosing medicine as an academic major appeared to be personality factors, such as social status [45]. In Faculty of Medicine of Pennsylvania University, 90 percent of the students were satisfied with the instructional programs and the majority of them were interested in research-oriented jobs in academic centers [46]. In another study, the motivation in students of dentistry was reported differently across males and females [47].

\subsection{Research Questions}

The main purpose of this study was to search the role of academic motivation in the relation between academic self-efficacy and academic procrastination. In other words, the study examined whether academic motivation might play a mediating role between academic self-efficacy and academic procrastination.

To this end, the following research questions were posed:

1. What are the relationships between academic self-efficacy, academic motivation, and academic procrastination?

2. Is academic self-efficacy a predictor of academic procrastination?

3. Is academic motivation a predictor of academic procrastination?

4. Does academic motivation mediate the relationship between self-efficacy and academic procrastination?

\section{Method}

\subsection{Participants and Procedure}

The data for the present study was collected from three hundred nineteen university students (218 females and 101 males) enrolled in the education faculty of a private university in Istanbul, Turkey. Of the participants, 115 were freshmen, 125 were sophomores and 77 were juniors. The data was collected from three departments (English Language Teaching, Counseling and Guidance and Special Education). The participants' ages ranged from 18 to 42 , with an average age of 21.44 . The participants filled out the questionnaires in their regular classroom hour. There was no time limitation to complete the questionnaires.

\subsection{Measures}

\subsubsection{Academic Procrastination}

Academic procrastination was measured using the Aitken Procrastination Inventory [48]. As to collect data for the current study, a Turkish version of the inventory adapted by Balk1s [49] was used. The inventory consists of 19 items through which participants report their academic procrastination. The statements in the inventory are rated on a 5-point Likert scale with response options of false, mostly false, sometimes false/sometimes true, mostly true, and true. In the current study, the Cronbach alpha coefficient for this scale measured .83 .

\subsubsection{Academic Self-efficacy}

In order to measure academic self-efficacy on the part of the participants of the current study, the Academic Self-Efficacy Scale was used, as originally developed by Jerusalem and Schwarzer [50] and adapted to Turkish by Yılmaz, Gürçay, and Ekici [51]. The scale consists of 7 items rated on a 4-point Likert scale. The Cronbach alpha coefficient for this scale was measured at .71.

\subsubsection{Academic Motivation}

Academic motivation was measured using the Academic Motivation Scale developed by Bozanoğlu [52]. The scale consists of 20 items rated on a 5-point Likert scale. In the current study, Cronbach alpha coefficient for this scale was .90 .

\section{Results}

The data analysis section is presented step by step, by restating each research question and presenting the related analysis.

1. What are the relationships between academic self-efficacy, academic motivation, and academic procrastination?

To answer the abovementioned question, the Pearson Product-moment Test was used, the results of which are presented in Table 1.

Table 1. Correlations between Academic Self-efficacy, Motivation, and Procrastination

\begin{tabular}{|c|c|c|}
\hline & $\begin{array}{c}\text { Academic } \\
\text { Motivation }\end{array}$ & $\begin{array}{c}\text { Academic } \\
\text { Procrastination }\end{array}$ \\
\hline $\begin{array}{c}\text { Academic } \\
\text { Self-efficacy }\end{array}$ & $.407 * *$ & $-.312 * *$ \\
\hline $\begin{array}{c}\text { Academic } \\
\text { Motivation }\end{array}$ & & $-.482 * *$ \\
\hline
\end{tabular}

The table reveals that while academic self-efficacy has a positive relationship with academic motivation $(\mathrm{r}=.407)$, its relationship with academic procrastination is negative $(\mathrm{r}=-.312)$. The relationship between academic procrastination and academic motivation is also negative $(\mathrm{r}=-.482)$.

2. Is academic self-efficacy a predictor of academic procrastination?

3. Is academic motivation a predictor of academic procrastination? 
To answer the abovementioned questions, multiple regression analysis was applied. First of all, a number of assumptions for regression analysis were tested before the main analysis. The sufficient sample size in regression analysis is calculated using $\mathrm{N}>50+8 \mathrm{~m}$ formula. For this study, the minimum number of participants required was 66, which was fulfilled given the 319 participants of the study. In addition, multicollinearity, singularity, and linearity were examined based on the criterion that the correlation should not exceed .80 between each pair of variables. This assumption was met also. Lastly, probability plot and scatter plot for normality assumption disclosed that the data has a normal and linear distribution for the sample. Also, to check for outliers and normality Mahalonobis and Cook's distances were calculated. Having two predictor variables, the value for the Mahal distance was found 13.72. For Cook's distance values larger than 1 are a source of concern [54]. In this study it was found .093 . As a result, all the assumptions seemed to be met in order to carry out regression analysis.

\section{Regression Analysis}

After preliminary analysis, regression analysis was conducted. Results are shown in Table 2.

Table 2. Regression Analysis Results Regarding Academic Procrastination Behavior of University Students According to Academic Self-efficacy and Academic Motivation

\begin{tabular}{|c|c|c|c|c|c|c|}
\hline \multirow[b]{2}{*}{ Variables } & \multicolumn{2}{|c|}{ Unstandardized Coefficients } & \multirow{2}{*}{$\begin{array}{c}\text { Standardized } \\
\text { Coefficients }\end{array}$} & \multirow[b]{2}{*}{$\mathrm{t}$} & \multirow[b]{2}{*}{$\mathrm{R} 2$} & \multirow[b]{2}{*}{$\mathrm{F}$} \\
\hline & B & Std. Error & & & & \\
\hline \multicolumn{7}{|l|}{ Academic Procrastination } \\
\hline (Constant) & 70.548 & 3.368 & & $20.946 * *$ & & \\
\hline Academic self-efficacy & -.409 & .157 & -.139 & $-2.605 *$ & .25 & $52.131 * *$ \\
\hline Academic motivation & -.333 & .042 & -.425 & $-7.955 * *$ & & \\
\hline
\end{tabular}

$* \mathrm{p}<.05 * * \mathrm{p}<.001$

The conclusion that can be drawn from Table 2 is that close to 25 percent of variation in the participants' scores can be predicted by the two variables of academic self-efficacy and academic motivation. Overall model has been successful in predicting the participants' procrastination as a result of self-efficacy and motivation $[\mathrm{F}(2 ; 316)=52.131$; $\mathrm{p}<.001]$ Apparently academic self-efficacy $(\beta=-.139 ; \mathrm{p}<.05)$ and academic motivation $(\beta=-.425 ; \mathrm{p}<.001)$ both have been able to significantly predict the participants' academic procrastination.

4. Does academic motivation mediate the relationship between self-efficacy and academic procrastination?

To answer the abovementioned question, partial correlation was calculated to single out the effect of self-efficacy on procrastination by controlling for the effect of motivation. Table 3 presents the results of this test.

Table 3. Partial Correlation Showing the Effect of Self-efficacy on Procrastination after Controlling for the Effect of Motivation

\begin{tabular}{|c|c|c|c|c|c|}
\hline \multicolumn{2}{|c|}{ Control Variables } & & $\begin{array}{c}\text { academic } \\
\text { self-efficacy }\end{array}$ & $\begin{array}{c}\text { academic } \\
\text { procrastination }\end{array}$ & $\begin{array}{c}\text { academic } \\
\text { motivation }\end{array}$ \\
\hline \multirow{3}{*}{- none- $^{\mathrm{a}}$} & \multirow{3}{*}{$\begin{array}{c}\text { academic } \\
\text { self-efficacy }\end{array}$} & Correlation & 1.000 & -.312 & .407 \\
\hline & & Significance (2-tailed) & . & .000 & .000 \\
\hline & & $\mathrm{df}$ & 0 & 317 & 317 \\
\hline \multirow{3}{*}{ academic motivation } & \multirow{3}{*}{$\begin{array}{c}\text { academic } \\
\text { self-efficacy }\end{array}$} & Correlation & 1.000 & -.145 & \\
\hline & & Significance (2-tailed) & . & .010 & \\
\hline & & $\mathrm{df}$ & 0 & 316 & \\
\hline
\end{tabular}

This table shows that when the effect of motivation is not controlled for, self-efficacy has a negative correlation of -.312 with academic procrastination. But, when motivation is also added to the equation, the negative correlation reduces to -.145 . This finding suggests that motivation mediates the relationship between self-efficacy and procrastination positively. That is, students with higher motivation procrastinate less compared to students with lower motivation. 


\section{Conclusions}

The current study was an investigation of the relationship among academic self-efficacy, academic procrastination and academic motivation. Firstly, it was examined whether academic self-efficacy and academic motivation are predictors of academic procrastination. In addition, the mediating role of academic motivation in the relationship between academic self-efficacy and academic procrastination was also assessed. The results of a regression analysis indicated that academic self-efficacy and academic motivation were significant and inverse predictors of procrastination. Individuals with strong academic self-efficacy and academic motivation tended to report less procrastination. Another result derived from this study is the relationship between academic self-efficacy and academic procrastination was partially mediated by academic motivation.

These findings are consistent with the few studies [55-58]. Kandemir [55] found that academic success mean, self-regulation and life satisfaction predicted academic procrastination. Likewise, Klassen, Krawchuk and Sukaina [56] reported that self-regulation, academic self-efficacy, self-esteem, and self-efficacy for self-regulation are related to procrastination. Among these, self-efficacy for self-regulation appears the most predictive of procrastination tendencies.

In another study carried out by Tan [58], it was found that self-efficacy for self-regulated learning was significantly and negatively related to procrastination. High self-efficacy for self-regulated learning also predicted students' expectations of doing well and low self-efficacy for self-regulated learning predicted students' expectations of not doing well academically. Besides, Lee [57] indicated that high procrastination was associated with lack of self-determined motivation and low incidence of flow state. In addition to this, motivation and intrinsic motivation showed significantly unique effects on procrastination [59]. Academic motivation predicted academic procrastination, yet self-efficacy did not make a unique contribution to the model beyond the variance accounted for by academic motivation. In contrast with our own study, Azar [60] concluded that academic procrastination is inversely a significant predictor of academic achievement. In our study, however, we have observed that academic motivation is a predictor of academic procrastination.

This study's result is important for several reasons. The study suggests the importance of academic self-efficacy and academic motivation on academic procrastination as it can be a substantive problem for some students [19], and the reasons for and functions of task postponement have gained a great deal of research attention over the last ten years. Thanks to a better understanding of the reasons beyond academic procrastination, important methods may be found in order to discourage procrastinating and, it is hoped, increase academic success.

Furthermore, preventative or treatment programs which harness such methods may be developed with the aim of combatting procrastination in school settings. Such intervention programs already in operation have focused on cognitive techniques such as time management [18, $61,62]$, and motivation strategies and were found effective. The effort to develop psycho-educational programs to minimize procrastination among college students including other factors such as self-efficacy, self-confidence, managing daily activities is of vital importance in gaining success.

The study has some implications both for teacher candidates and teacher trainers. It would be beneficial to integrate awareness raising activities and a specially designed training program emphasizing such concepts as academic motivation, academic self- efficacy and academic procrastination into the curriculum in the faculty of education. Through such training, teacher candidates can become aware of the importance of these concepts and develop strategies to cope with them in their professional life as a teacher.

Several limitations should be considered in interpreting the findings of this study. For one, our sample was limited in size and diversity. In addition, the cross-sectional, correlational design limited the conclusions that could be drawn about the direction and nature of the relationships observed. Due to this lack of control, extraneous variables could have influenced participant response.

\section{REFERENCES}

[1] Noel, L., Levitz, R., \& Saluri, D. (1985). Increasing student retention: Effective programs and practices for reducing dropout rate. San Francisco, CA: Jossey-Bass.

[2] Ames, C. (1992). Classrooms: goals, structures, and student motivation. Journal of Educational Psychology, 84, 261-271.

[3] Amirkhan, J. H. (1998). Attributions as predictors of coping and distress. Personality and Social Psychology Bulletin, 24, 1006-1018.

[4] Covington, M. V. (1993). A motivational analysis of academic life in college. In J. Smart (ed.), Higher Education: Handbook of Theory and Research, Vol. 9, pp. 50-93. New York: Agathon Press.

[5] Bandura, A. (1982). Self-efficacy mechanisms in human agency. American Psychologist, 37, 122-147.

[6] Scheier, M. F., \& Carver, C. S. (1985). Optimism, coping, and health: Assessment and implications of generalized outcome expectancies. Health Psychology, 4, 219-247.

[7] Ackerman, D. S., \& Gross, B. L. (2005). My instructor made me do it: Task characteristics of procrastination. Journal of Marketing Education, 27, 5-13. 
[8] Ellis, A., \& Knaus, W. J. (1977). Overcoming procrastination. New York, NY: Institute for Rational Living.

[9] Ferrari, J. R., Johnson, J. L., \& McCown, W.G. (Eds.). (1995). Procrastination and task avoidance: Theory, research and treatment. New York, NY: Plenum Press.

[10] Rothblum, E. D., Solomon, L. J., \& Murakami, J. (1986). Affective, cognitive, and behavioral differences between high and low procrastinators. Journal of Counseling Psychology, 387-394.

[11] Ferrari, J. R., Parker, J. T., \& Ware, C. B. (1992). Academic procrastination: Personality correlates with Myers-Briggs types, self-efficacy, and academic locus of control. Journal of Social Behavior and Personality, 7, 495-502.

[12] Ferrari, J. R. \& Tice, D. M. (2000). Procrastination as a self-handicap for men and women: A task-avoidance strategy in a laboratory setting. Journal of Research in Personality, 34, 73-83.

[13] Judge, T. A., \& Bono, J. E. (2001). Relationship of core self-evaluations traits-self-esteem, generalized self-efficacy, locus of control, and emotional stability - with job satisfaction and job performance: A meta-analysis. Journal of Applied Psychology, 86, 80-92.

[14] Kachgal, M. M., Hansen, L. S., \& Nutter, K. J. (2001). Academic procrastination prevention/intervention: Strategies and recommendations. Journal of Developmental Education, 25, 14-20.

[15] Pychyl, T. A., Coplan, R. J., \& Reid, P. A. (2002). Parenting and procrastination: Gender differences in the relations between procrastination, parenting style and self-worth in early adolescence. Personality and Individual Differences, $33,271-285$.

[16] Antony, M. M., Purdon, C. L., Huta, V., \& Swinson, R. P. (1998). Dimensions of perfectionism across the anxiety disorders. Behavior Research and Therapy, 36, 1143-1154.

[17] Stoeber, J., \& Joormann, J. (2001). Worry, procrastination and perfectionism: Differentiating amount of worry, pathological worry, anxiety and depression. Cognitive Therapy and Research, 25, 49-60.

[18] Van Eerde, W. (2003). A meta-analytically derived nomological network of procrastination. Personality and Individual Differences, 35, 1401-1418.

[19] Steel, P. (2007). The nature of procrastination: a meta-analytic and theoretical review of quintessential self-regulatory failure. Psychological Bulletin, 133(1), $65-94$.

[20] Johnson, J. L., \& Bloom, A. M. (1995). An analysis of the contribution of the five factors of personality to variance in academic procrastination. Personality and Individual Differences, 18, 127-133.

[21] Lee, D. G., Kelly, K. R., \& Edwards, J. K. (2006). A closer look at the relationships among trait procrastination, neuroticism, and conscientiousness. Personality and Individual Differences, 40, 27-37.

[22] Milgram, N. \& Tenne, R. (2000). Personality correlates of decisional and task avoidant procrastination. European Journal of Personality, 14, 141-156.
[23] Schouwenburg, H. C., \& Lay, C. H. (1995). Trait procrastination and the Big Five factors of personality. Personality and Individual Differences, 18, 481-490.

[24] Bandura, A. (1977). Self-efficacy: Toward a unifying theory of behavioral change. Psychological Review, 84(2), 191-215.

[25] Pajares. F. (2002). Overview of social cognitive theory and of self-efficacy. Available from: http://www.uky.edu/ eushe2/Pajares/eff.html.

[26] Bandura, A. (1997). Self-efficacy: The exercise of control. New York, NY, US: W. H. Freeman and Company.

[27] Eccles, J. S., \& Wigfield, A. (2002). Motivational beliefs, values, and goals. Annual Review of Psychology, 53, 109-132.

[28] Elias, S. M., \& Loomis, R. J. (2002). Utilizing need for cognition and perceived self-efficacy to predict academic performance. Journal of Applied Social Psychology, 32, $1687-1702$.

[29] Linnenbrink, E. A., \& Pintrich, P. R. (2002). Motivation as enabler of academic success. School Psychology Review, 31, 313-327.

[30] Schunk, D. H., \& Pajares, F. (2002). The development of academic self-efficacy. In A. Wigfield \& J. Eccles (Eds.), Development of achievement motivation (pp.15-31). San Diego, CA: Academic Press.

[31] Bedel, F. E. (2014). Exploring academic motivation, academic self-efficacy and attitudes toward teaching in pre-service early childhood education teachers. Journal of Education and Training Studies, 4(1), 142-149.

[32] Husain, U.K. (2014). Relationship between Self-Efficacy and Academic Motivation. International Conference on Economics, Education and Humanities (ICEEH'14) Dec. 10-11, 2014 Bali (Indonesia).

[33] Ateş, H., \& Saylan, A. (2015). Investigation of pre-service science teachers' academic self-efficacy and academic motivation toward biology. $2^{\text {nd }}$ International Eurasian Educational Research Congress (EJER Congress 2015), Hacettepe University, Ankara, Turkey.

[34] Amrai, K., Motlagh, S. E., Zalani, H. A. \& Parhon, H. (2011). The relationship between academic motivation and academic achievement students. Procedia Social and Behavioral Sciences, 15, 399-402.

[35] Jones, B. D. (2009). Motivating students to engage in learning: the music model of academic motivation. International Journal of Teaching and Learning in Higher Education, 21(2), 272-285.

[36] Mallick, S., K., De, K. K., \& Mukhopadhyay, R. (2017). Academic motivation of secondary school students: a critical study. European Journal of Education Studies, 3(4), 661-673.

[37] Lang P. J., Bradley M. M. (2008). Appetitive and defensive motivation is the substrate of emotion. In A. J. Elliot (Ed.), Handbook of Approach and Avoidance Motivation (pp. 51-66) New York: Psychology Press.

[38] Sharma, D., \& Sharma, S. (2018). Relationship between motivation and academic achievement. International 
Journal of Advances in Scientific Research, 4(1): 01-05.

[39] Gupta, P.K. \& Mili, R. (2016). Impact of academic motivation on academic achievement: a study on high school students. European Journal of Education Studies, 2(10), 43-51.

[40] Hirunval, A. (1980). A study of pupils' self-concept, academic motivation, classroom climate and academic performance. In M.B Buch (Ed.), Third Survey of Research in Education (pp.666-667). New Delhi: NCERT.

[41] Krishnamurthy, S. (2000). Achievement as related to academic achievement motivation and attitude towards study of history. The Education Review, 106, 95-98.

[42] Köseoğlu, Y. (2012). Academic Motivation of the first-year university students and the self-determination theory. Educational Research and Reviews.

[43] Abouserie, R. (1995). Self-esteem and achievement motivation as determinants of students ${ }^{\text {ee }}$ approaches to studying. Studies in Higher Education, 20(1), 19-26.

[44] Busato V, V., Prinsb, F. J., Elshouta, J. J., \& Hamakera, C.H (2009). Intellectual ability, learning style, personality, achievement motivation and academic success of psychology students in higher education. Available from: http://www.sciencedirect.com/science?_ob=ArticleURL\& _udi=B6V9F-412RS3P.

[45] Hajian K., \& Nasiri, A. (2003). Evaluation of medical students' attitude toward future job. Journal of Babol University of Medical Sciences, 29(8), 95-86.

[46] Watt, C. D., Greeley, S.A., Shea, J. A., \& Ahn, J. (2005). Educational views and attitudes, and career goals of MD-PhD students at the University Of Pennsylvania School Of Medicine. Acad Med, 80(2), 193-198.

[47] Gallagher, J. E., Patel, R., Donaldson, N., \& Wilson, N. H (2007). The emerging dental workforce: Why dentistry? A quantitative study of final year dental students' views on their professional career. BMC Oral Health, 7(7), 1-16.

[48] Aitken, M. (1982). A personality profile of the college student procrastinator. Unpublished doctoral dissertation, University of Pittsburgh.

[49] Balkıs, M. (2006). Öğretmen adaylarının davranışlarındaki erteleme eğiliminin, düşünme ve karar verme tarzları ile ilişkisi. Yayımlanmamış Doktora Tezi. Dokuz Eylül Üniversitesi Eğitim Bilimleri Enstitüsü, İzmir.

[50] Jerusalem, M. \& Schwarzer, R. (1981). Fragebogen zur Erfassung von "Selbstwirksamkeit. Skalen zur
Befindlichkeit und Persönlichkeit In R. Schwarzer (Hrsg.). (Forschungsbericht No. 5). Berlin: Freie Universität, Institut für Psychologie.

[51] Yılmaz, M., Gürçay, D., ve Ekici, G. (2007). Akademik Öz-yeterlik Ölçeğinin Türkçe'ye uyarlanması. Hacettepe Üniversitesi Eğitim Fakültesi Dergisi, 33, 253-259.

[52] Bozanoğlu, İ. (2004). Akademik Güdülenme Ölçeği: Geliştirmesi, geçerliği, güvenirliği. Ankara Üniversitesi Eğitim Bilimleri Fakültesi Dergisi, 37(2), 83-98.

[53] Bachman, L. F. (2004). Statistical analyses for language assessment. Cambridge: Cambridge University Press.

[54] Pallant, J. (2013). SPSS survival manual. New York: The McGraw Hill Companies.

[55] Kandemir, M. (2014). Reasons of academic procrastination: Self- regulation, academic self-efficacy, life satisfaction and demographics variables. Procedia - Social and Behavioral Sciences, 152, 188-193.

[56] Klassen, R.M., Krawchuk, L.L., \& Rajani, S. (2008), Academic procrastination of undergraduates: low self-efficacy to self-regulate predicts higher levels of procrastination. Contemporary Educational Psychology, 33(4), 915-931.

[57] Lee, E. (2005). The relationship of motivation and flow experience to academic procrastination in university students. The Journal of Genetic Psychology, 166, 5-14.

[58] Tan, C. X., Ang, R. P., Klassen, R. M., Yeo, L. S., Wong, I. Y. F., Huan, V. S., \& Chong, W. H. (2008). Correlates of academic procrastination and students' grade goals. Current psychology-Research \& reviews, 27(2), 135-144.

[59] Cerino E. S. (2014). Relationships between academic motivation, self-efficacy, and academic procrastination. Psi Chi Journal of Psychological Research, 19(4), 156-163.

[60] Azar, F. S. (2013). Self-efficacy, Achievement Motivation, and Academic Procrastination as Predictors of Academic Performance. US-China Education Review, 3(11), 847-857.

[61] Ramsay, R. J. (2002). A cognitive therapy approach for treating chronic procrastination and avoidance: Behavioral activation interventions. Journal of Group Psychotherapy, Psychodrama, and Sociometry, 55, 79-92.

[62] Wang, M., Qian, M., Wang, W., \& Chen, R. (2011). Effects of group counseling based on self-efficacy for self-regulated learning in students with academic procrastination. Chinese Mental Health Journal, 25, 921-926. 